\title{
Induced reproduction in a migratory teleost species by water level drawdown
}

\author{
Chayrra Chehade, Mônica Cassel and Maria Inês Borella
}

Captive reproduction is one of the problems faced in aquaculture requiring the manipulation of environmental factors and/ or hormonal treatment. Thus, we seek to verify experimentally which gonadal changes were present in mature individuals of Astyanax altiparanae arising from decreased water level. Collections were made every four hours, initiated four hours before and finished 28 hours after stimulation, at the Fish Farming Station of Companhia Energética de São Paulo, São Paulo, Brazil. The gonads were analyzed by light microscopy. The females had ovaries in the spawning capable phase until $12 \mathrm{~h}$; in $16 \mathrm{~h}$, in a more advanced stage of spawning capable phase; and, from $20 \mathrm{~h}$, in the regressing phase. Males had testes in the spawning capable phase until 8h; in 12h, in a more advanced stage of spawning capable phase; and, from 16h, the return to the spawning capable phase. The morphological description was corroborated by the proportion of cell classes. Females presented variation on the gonadosomatic index, but it was not found an emptying of the gonad for neither sex. The process of inducing reproduction with water level drawdown was considered satisfactory, since both sexes presented a reduction in the number of mature gametes at the end of the sample period.

Reprodução em cativeiro é um dos problemas enfrentados na aquicultura exigindo a manipulação de fatores ambientais e/ ou tratamento hormonal. Assim, verificou-se experimentalmente as alterações gonadais presentes em indivíduos adultos de Astyanax altiparanae decorrentes da diminuição do nível da água. As coletas foram realizadas a cada quatro horas, iniciadas quatro horas antes e encerradas 28 horas após a estimulação, na Estação de Piscicultura da Companhia Energética de São Paulo, São Paulo, Brasil. As gônadas foram analisadas por microscopia de luz. As fêmeas apresentaram ovários na fase de apto à reprodução até $12 \mathrm{~h}$; em $16 \mathrm{~h}$, um estágio mais avançado desta fase; e, a partir das $20 \mathrm{~h}$, na fase de regressão. Os machos tiveram os testículos em fase de apto à reprodução até $8 \mathrm{~h}$; em $12 \mathrm{~h}$, um estágio mais avançado desta fase; e, a partir das $16 \mathrm{~h}$, o retorno à fase de apto à reprodução. A descrição morfológica foi corroborada pela proporção das classes celulares. As fêmeas apresentaram variação no índice gonadossomático, mas não foi estabelecido o esvaziamento das gônadas para nenhum dos sexos. O processo utilizado para a indução à reprodução foi considerado satisfatório, uma vez que ambos os sexos apresentaram redução no número de gametas maduros no final do período de amostragem.

Keywords: Asynchronous reproduction, Characidae, Gametogenesis, Gonadosomatic index, Histology.

\section{Introduction}

The seasonal reproduction in fish occurs due to the interaction of physiological functions with environmental cycles(Bollough, 1939; Sundararaj \& Vasal, 1976; Sundararaj et al., 1980). Environmental factors act such as flags of a favorable station to reproduction, which are perceived by external receptors, and therefore affect the central nervous system, pituitary, and gonads (Rocha \& Rocha, 2006). The specific environmental factors that stimulate fish reproductive period as in elimination of gametes, gonadal maturation, or even in migratory movements, are still not very clear. A combination of factors such as photoperiod, temperature, increasing of water level and food availability associated with physiological variations of the individual may possibly be involved in the regulation of different stages of the reproductive cycle (Bailly et al., 2008).

Increases in temperature and photoperiod have been the main factors associated with gonadal maturation (Suzuki et al., 2004). However, in latitudes where the seasonal temperature fluctuations are small, flooding seems to be the main trigger for the reproduction of many fish species (Agostinho et al., 2004). The beginning of the flooding cycle seems to start a synchronization process for events of

Department of Cell and Developmental Biology, Institute of Biomedical Sciences, University of São Paulo. Av. Prof. Lineu Prestes 1524, Butantã, 05508-900 São Paulo, SP, Brazil. (CC) chayrra_bio@yahoo.com.br (corresponding author); (MC) monica_cassel@usp. br; (MIB)<miborell@usp.br. 
spawning and the peak of flood level would signal its end (Suzuki et al., 2004). Thus, the floods have an essential role in spawning stage (Godoy, 1975), while the first rains after the dry season are considered stimuli for the formation and movement of migratory fish shoal (Agostinho et al., 2003).

Migratory species need to move in order to find an ideal environment to spawn, so significant environmental changes to successful reproduction of the species occur during migration. However, when they are contained in tanks, they are deprived of these changes, which results in failure in reproduction (Mylonas \& Zohar, 2007). Thus, the reproduction of migratory species in captivity in most cases does not occur naturally, and to obtain reproductive success in these conditions the manipulation of environmental parameters or some hormonal induction is necessary (Mylonas \& Zohar, 2007). The main problem encountered in aquaculture is the dysfunction in the maturation of oocytes (Mylonas \& Zohar, 2007) that usually happens due to the lack of an appropriate environmental stimulus or by the presence of a stressor in captivity (Schreck et al., 2001). Another failure is the release of oocytes to the external environment (spawning) (Bromage \& Cumaranatunga, 1988; Zohar et al., 1989), which probably occurs by the deficiency in the synchronization of gonadal changes in females.

A large group of migratory species belongs to the Characidae family, which represents the largest number of fish species in Brazil, with worldwide distribution (Britski, 1972). In this group lies the genus Astyanax, considered the mostrepresentative of the Tetragonopterinae subfamily, being one of the dominant genera in South America (Eigenmann, 1921). This genus shows wide distribution in the Neotropics and has approximately a hundred species (Garutti \& Britski, 2000).

Astyanax includes species which, in general, are reofilics, small, and are characterized by having small oocytes, high relative fecundity, rapid development, external fertilization and no parental care (Agostinho et al., 1999; Suzuki et al., 2005). Among the species of this genus, Astyanax altiparanae is characterized by being small, fast growing, reaching sexual maturity at about four months of age in farming conditions, and displays sexual dimorphism (Porto-Foresti et al., 2001). According to Dias et al. (2005), the duration of the reproductive period seems to gradually become longer after the flood, however Garutti (1989) and Peres et al. (2005) found that Astyanax altiparanae shows a period of prolonged mating in shallow waters, whereas in deep water environments it tends to have a short reproductive period.

The construction of dams, overfishing, pollution, introduction of exotic species, and other anthropogenic factors are leading to a population decline of some native species, after that the captive reproduction becomes an important tool for the conservation of fish species (Machado, 1975). However, it is important to have knowledge of reproduction techniques, so the containment of the species would not be a hindrance to reproduction. Thus, the Astyanax altiparanae was used as a model due to the characteristics already mentioned and the fact that this species is heavily livestock potential and high plasticity. Moreover, as no standard for characterizing reproduction has been described so far, and considering what has been described in the literature for Astyanax altiparanae, we seek to find experimentally which gonadal alterations are present in mature individuals under induced reproduction by water level drawdown.

\section{Material and Methods}

The experiment and the collections were conducted in February and March 2012, in Fish Farming Station of Companhia Energética de São Paulo (CESP) in Paraibuna, São Paulo, Brazil $\left(23^{\circ} 24^{\prime} 47^{\prime \prime} S 4^{\circ} 36^{\prime} 7^{\prime} \mathrm{W}\right)$. Voucher specimens are deposited at the Museu de Zoologia da Universidade de São Paulo (MZUSP 113746). Before the experiment the specimens of both sexes were kept together in an outdoor tank with natural photoperiod regime and hand fed once a day. For the induction process the following steps were carried out:

1) Mature individuals of both sexes were separated and acclimated in indoor tanks under natural photoperiod and running water $\left(23.3 \pm 0.7^{\circ} \mathrm{C}, \mathrm{pH} 6.5 \pm 0.3,336.7 \pm 16.4 \mathrm{mV}\right.$, $7.6 \pm 1.2 \mathrm{mg} / \mathrm{L} \mathrm{DO}$ ) in ratio of 4 females per male;

2) On the next day, the specimens were put together around $8 \mathrm{AM}$ in a tank with water level reduced by approximately $50 \%$, but keeping the running water to oxygenation;

3) For this study, samples were collected every four hours interval, beginning four hours before reducing the water level and maintained until 28 hours after.

At each sampling time, the gonads of 16 females and four males were collected, keeping the initial sex ratio. The animals were anesthetized by an alcoholic solution of benzocaine $(100 \mathrm{mg} / \mathrm{L})$, there after they were euthanized by spinal cord section, in accordance with the procedure approved by the Ethics Committee on Animal Experiments of the Institute of Biomedical Sciences (USP Proc. 2011/017). The classification of male and female individuals was based on their sexual dimorphism, where males presented spines on the anal fin (Garutti \& Britski, 2000). Individuals had the total weight $(\mathrm{Wt})$ and gonad weight $(\mathrm{Wg})$ measured on an analytical balance (Marte AL500) with an accuracy of $0.001 \mathrm{~g}$.

The gonads were isolated and fixed in Bouin's solution for 24 hours. After fixing procedure, they were washed in water, dehydrated in increasing alcohol concentrations, cleared in xylene solution and embedded in Paraplast. The blocks were cut in $5 \mu \mathrm{m}$ thick, obtaining semi-serial sections with approximately $200 \mu \mathrm{m}$ of distance between each other. Each slide contained three sections, subsequently stained with hematoxylin/eosin. The sections were used for morphological characterization of gonads throughout the sampling times previously determined.

To check the gonadal variation over sampling times, the gonadosomatic index (GSI) of both sexes was estimated. The comparison between the GSI through times, after 
verification of data normality by Lilliefors test, was made using parametric statistical test ANOVA for males and nonparametric statistical test of Kruskal-Wallis for females.

All the histological sections were used to quantitatively evaluate the distribution of germ cell types present in the gonads during the sampling times. For females, $n=10$ individuals for each sampling time were randomly selected. The cell types were counted in the total area of each section. The germinal epithelium was discriminated in: oogonia, initial oocyte, pre-vitellogenic oocyte, vitellogenic oocyte, mature oocyte, post-ovulatory complexes, and atresia (adapted from Quagio-Grassiotto et al., 2011). All males were measured according to the area occupied by each cell type in 10 tubules by section. The germ cell types were discriminated in: spermatogonia, primary spermatocyte, secondary spermatocyte, spermatid and spermatozoid (adapted from Schulz et al., 2010).

Subsequently, the quantitative data of both sexes were used for analysis of the cellular proportion of classes, by sampling time, which allowed the classification of gonadal cycle phases in accordance with Brown-Peterson et al. (2011). Finally, to determine if there was emptying of the gonads, it was compared the total number of post-ovulatory complex of each female and the total area occupied by spermatozoid in each male per sample time, using KruskalWallis and ANOVA statistical tests, respectively.

\section{Results}

The females had ovaries filled with vitellogenic oocytes, some pre-vitellogenic oocytes and few initial oocytes between the sampling periods $-4 \mathrm{~h}$ and $4 \mathrm{~h}$ (Fig. 1A). Added to the above characteristics, in the periods of $8 \mathrm{~h}$ and $12 \mathrm{~h}$, some post-ovulatory complexes were observed (Fig. 1B), featuring the gonads in spawning capable phase. At 16h, was verified the presence of many oocytes with germinal vesicle breakdown, also known as mature oocytes, few post-ovulatory complexes and initial oocytes (Fig. 1C), indicating the spawning capable phase, but in the advanced actively spawning subphase. Then, gradually the females had ovaries with post-spawning characteristics: with loads of post-ovulatory complexes, initial oocytes and atresia, and some pre-vitellogenic oocytes, setting the regressing phase (Fig. 1D).

Males showed a great amount of all germ cell classes during the sampling periods from $-4 \mathrm{~h}$ to $8 \mathrm{~h}$, with emphasis on the proliferation of spermatogonia and primary spermatocytes (Fig. 1E), showing spermatozoa in the lumen of the tubule, characterizing the spawning capable phase. At $12 \mathrm{~h}$, the gonads were full of sperm and secretion, with almost complete differentiation of other cell classes (Fig. $1 \mathrm{~F})$, in the spawning capable phase, but in the advanced actively spawning subphase. Then, the gonads showed a partial elimination of sperm and retrieval of other germ cell types (Fig. 1G), returning of the primary stage of spawning capable phase.
For quantitative analysis, it was observed that the proportion of cell classes corroborated the descriptive results for both females and males (Fig. 2A and 2C). The gonadosomatic index of females showed variation over the sampling periods $(H=16.388, p=0.037)$, indicating that they exhibit significant changes in gonad weight according to reproductive stimulation (Fig. 2B). Further, regarding the maximum emptying of ovary over time, it was found that the same does not occur during the sampled period $(\mathrm{H}=7.708, \mathrm{p}=0.463)$. For males, the gonadosomatic index did not vary $(\mathrm{F}=1.806, \mathrm{p}=0.120)$ and they did not exhibit an emptying of the testis during the sampling periods $(\mathrm{F}=1.612$, $\mathrm{p}=0.168$ ) (Fig. 2D), so spermatozoa were always present in the gonads.

\section{Discussion}

The water level drawdown applied to specimens in spawning capable phase of Astyanax altiparanae to induce reproduction was effective. The reducing of the water level can be considered a stressor and it is known that stress, most often, triggers a negative response in the reproductive success for both males and females (Consten et al., 2001; Mosconi et al., 2006; Cleary et al., 2007). The main factor involved in negative response to stress is cortisol, that in females appears to inhibit the synthesis of vitellogenin, which is modulated by estrogen (Pankhurst \& Van Der Kraak, 2000; Berg et al., 2004), and in males cortisol inhibits androgen synthesis, then slowing spermatogenesis (Consten et al., 2002; Ozaki et al., 2006).

However, these deleterious effects are associated with prolonged stimuli of aggressive agents resulting in high levels of plasma cortisol (Bayunova et al., 2002; Schreck, 2010). In animals at the final stages of the reproductive cycle, stress appears to have a positive effect on reproduction (Small, 2004; Westring et al., 2008; Milla et al., 2009). Previous studies have found that this effect may be observed especially in females, where treatment with corticosteroids (cortisol, 11-deoxycortisol, 11-deoxycorticosterona) induces ovulation in various fish species (Goetz \& Theofan, 1979; Haider \& Rao, 1994; Milla et al., 2009). Also, in males, high levels of cortisol in specimens of Morone saxatilis in captivity caused a precocious spermiation and prolonged the spermiation period (Castranova et al., 2005). This may explain what was observed in males of Astyanax altiparanae, which responded to the stimulus of water level stress before the females, suggesting that males show a greater sensitivity to a stress situation.

Furthermore, it is important to note that, in general, the natural process of reproduction demands a high energetic rate for the behavior of cohort and maturation of gametes, especially for migratory fish species (Schreck, 2010), as Astyanax altiparanae. This suggests that water stress may have been essential to achieve a favorable energy demand for this process, mimicking a physiological response as expected in natural reproduction. 


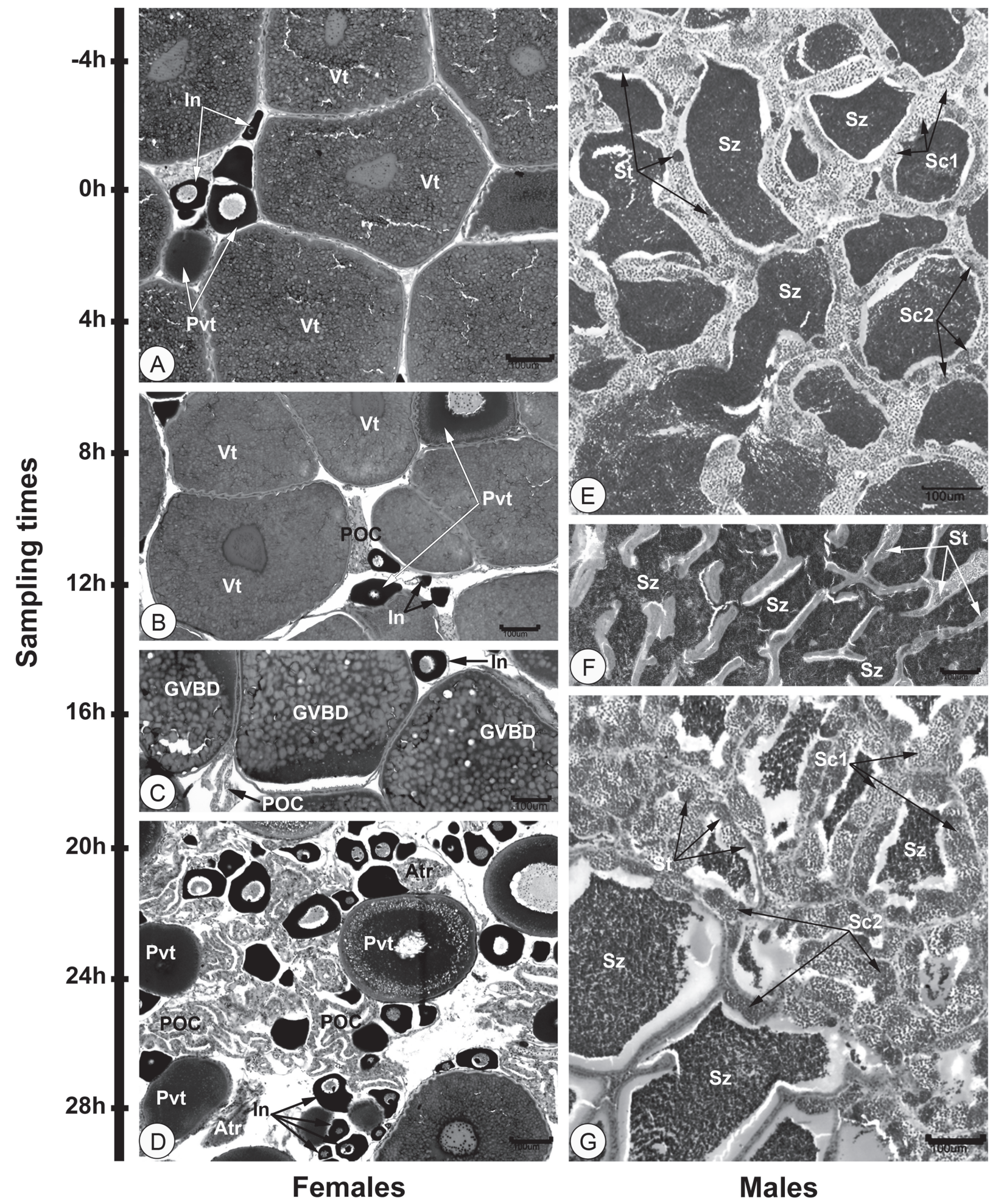

Fig. 1. Photomicrographs of gonads of Astyanax altiparanae over the sampling times (stained with hematoxylin-eosin). (A) Ovary in spawning capable phase from $-4 \mathrm{~h}$ to $4 \mathrm{~h}$; (B) Ovary in the same phase but with post-ovulatory complexes presents in $8 \mathrm{~h}$ and $12 \mathrm{~h}$; (C) Ovary in the advanced actively spawning subphase of the spawning capable phase at 16h; (D) Ovary during regressing phase from $20 \mathrm{~h}$ to $28 \mathrm{~h}$; (E) Testis in spawning capable phase from -4h to $8 \mathrm{~h}$; (F) Testis in the advanced actively spawning subphase of the spawning capable phase at $12 \mathrm{~h}$; (G) Testis returning the primary spawning capable phase from $16 \mathrm{~h}$ to $28 \mathrm{~h}$. In - initial oocytes; Pvt - pre-vitellogenic oocytes; Vt - vitellogenic oocytes; POC - post-ovulatory complexes; GVBD - mature oocytes (oocytes with germinal vesicle breakdown); Atr - atresias; Sc1 - primary spermatocyte; Sc2 - secondary spermatocyte; St - spermatids; Sz - spermatozoids. 

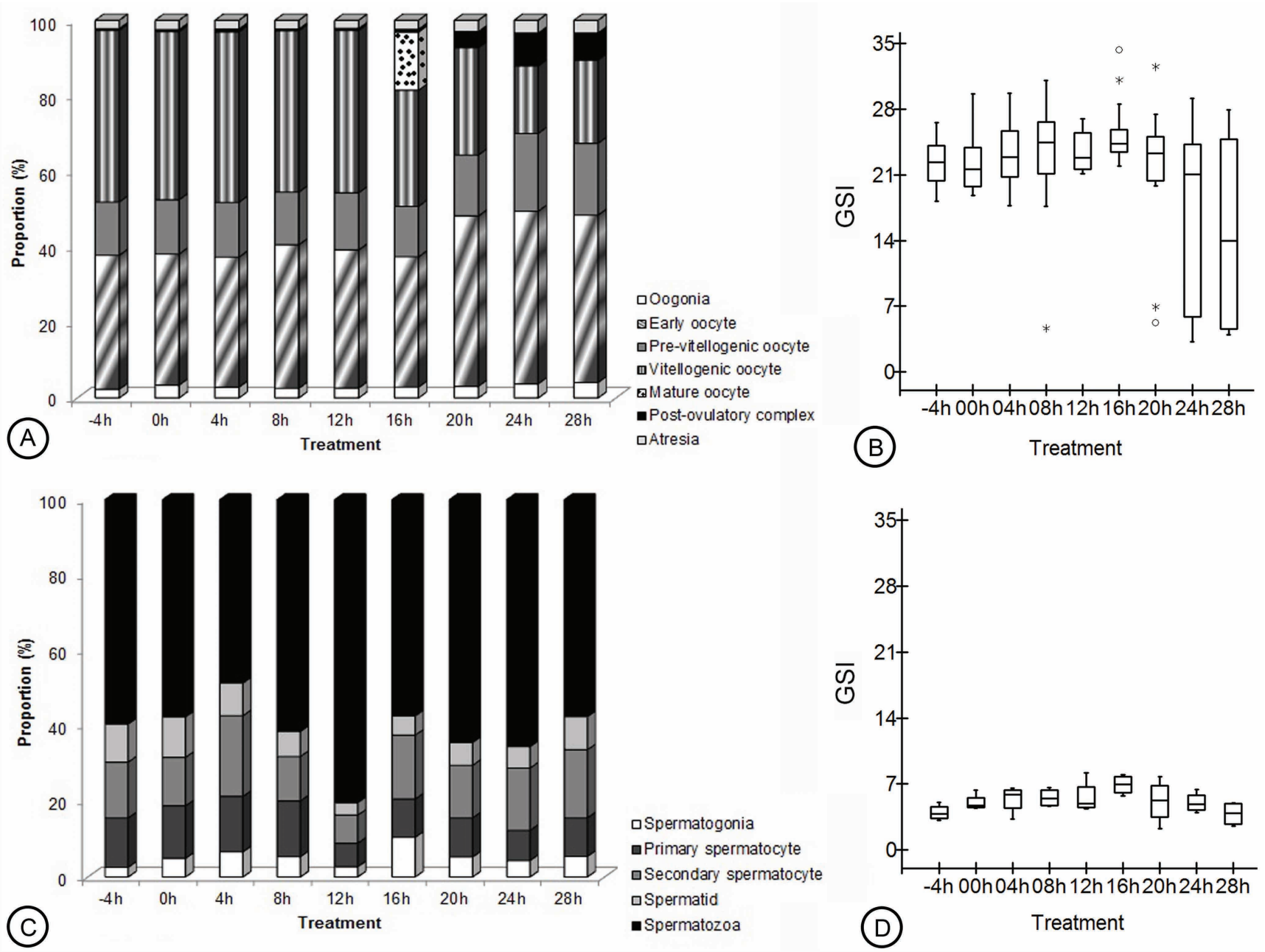

Fig. 2. Quantitative analyses of the gonads. (A) Plot of female germ cells proportion though sampling times; (B) Variation in female gonadosomatic index (GSI) over the sampling times $(\mathrm{H}=16.388, \mathrm{p}=0.037)$; (C) Plot of male germ cells proportion though sampling times; (D) Variation in male gonadosomatic index (GSI) over the sampling times ( $\mathrm{F}=1.806, \mathrm{p}=0.120)$.

This energetic demand is apparently stronger in females, especially because ovarian maturation and fecundity of the fish are directly linked to energy reserves (Milton et al., 1994). The availability of energy can cause variations in egg production (Coward \& Bromage, 1999; Marshall et al., 1999 ) with probable impact on ovarian allometry (Somarakis et al., 2004) and, therefore, in the gonadosomatic index (GSI) of the specimens. This fact may explain why the variation in the GSI happened in females, but not in males.

In addition to the GSI, specimens from both sexes did not present a complete emptying of the gonad, although spawning has been observed. This may be related to the reproductive strategy of Astyanax altiparanae. These strategies comprise a set of characteristics that the species must have to succeed in reproduction (Vazzoler, 1996). However, to the genus Astyanax the descriptions of reproduction are different among authors in the literature. For example, specimens of Astyanax bimaculatus from Ivaí River, upper Paraná River basin, exhibit spawning between November and February (Agostinho et al., 1984).
However, Nomura (1975) studying this species in the Mogi Guaçu River, São Paulo, noted that it shows total spawning between November and December. According to Rodrigues et al. (1992), Astyanax bimaculatus (=A. altiparanae) from Ibitinga dam has a total spawning, and reproduction is discontinuous, periodic and annual, with greater reproductive intensity from December to January.

For specimens of Astyanax altiparanae analyzed by Lizama \& Ambrosio (2002), by means of condition factor, three reproductive periods were found: August/September, November/January and March. However, observing the variations at more accurate levels, as histological characterization, it is possible to notice that this species, in captive conditions, presents split spawning, and may be classified as asynchronous in the reproductive season (Mylonas \& Zohar, 2007). This finding corroborates the observations in A. scabripinnis, which presented split spawning, with asynchronous development and showed the highest reproductive activity from November to April (Pereira-Filho et al., 2011). 
After all the analysis it can be inferred that the process of inducing reproduction by water level drawdown was satisfactory, since males and females showed a reduction in the number of mature gametes at the end of the sampling period. Regarding the induction time, it was observed that males of Astyanax altiparanae responded previously to the stimulus. Finally, according to the qualitative and quantitative analysis, we suggest that Astyanax altiparanae has an asynchronous development within the reproductive period for both sexes.

\section{Acknowledgments}

The authors acknowledge the fish culture station of Companhia Energética de São Paulo in Paraibuna for the specimens and laboratory lent to the development of the work; to the São Paulo Research Foundation (FAPESP) for the grants \#2010/17586-0 and \#2011/09567-8. We are grateful to the technicians Cruz Alberto Mendoza Rigonati and Adriane Pereira Fernandes Araujo by logistical assistance during the collection and processing of study material.

\section{References}

Agostinho, A. A., L. C. Gomes, H. I. Suzuki \& H. F. Júlio-Junior. 2003. Migratory fishes of the upper Paraná River basin, Brazil. Pp. 19-99. In: Carolsfeld, J., B. Harvey, C. Ross \& A. Baer (Eds.). Migratory Fishes of South America: biology, fisheries and conservation status. Victoria, World Bank and IDRC.

Agostinho, A. A., L. C. Gomes, S. Veríssimo \& E. K. Okada. 2004. Flood regime and fish: effects on spawning, recruitment and attributes of the assemblages in the upper Paraná River floodplain. Reviews in Fish Biology and Fisheries, 14: 11-19.

Agostinho, A. A., L. E. Miranda, L. M. Bini, L. C. Gomes, S. M. Thomaz \& H. I. Suzuki. 1999. Patterns of colonization in neotropical reservoirs, and prognosis on aging. Pp. 227-265. In: Tundisi, J. G. \& M. Straskraba (Eds.).Theoretical Reservoir Ecology and its Applications. São Carlos, International Institute of Ecology (IIE); Leiden, Netherlands, Backhuys Publishers.

Agostinho, C. A., S. L. Molinari, A. A. Agostinho \& J. R. Verani. 1984. Ciclo reprodutivo e primeira maturação sexual de fêmeas do lambari, Astyanax bimaculatus (L.) (Osteichthyes Characidae) do rio Ivaí, Estado do Paraná. Revista Brasileira de Biologia, 44: 31-36.

Bailly, D., A. A. Agostinho \& H. I. Suzuki. 2008. Influence of the flood regime on the reproduction of fish species with different reproductive strategies in the Cuiabá River, Upper Pantanal, Brazil. River Research and Applications, 24: 1218-1229.

Bayunova, L., I. Barannikova \& T. Semenkova. 2002. Sturgeon stress reactions in aquaculture. Journal of Applied Ichthyology, 18: 397-404.

Berg, A. H., C. Modig \& P. E. Olsson. 2004. 17beta-estradiol induced vitellogenesis is inhibited by cortisol at the posttranscriptional level in Arctic charr (Salvelinu salpinus). Reproductive Biology and Endocrinology, 2: 64.

Bollough, W. S. 1939. A study of the reproductive cycle of the minnow in relation to the environment. Proceedings of the Zoological Society of London, 109: 79-102.
Britski, H. A. 1972. Peixes de água doce do Estado de São Paulo: Sistemática. Pp. 79-108. In: Comissão Interestadual da Bacia Paraná-Uruguai. Poluição e Piscicultura. São Paulo, Faculdade de Saúde Pública da USP, Instituto de Pesca da C.P.R.N. da Secretaria da Agricultura.

Bromage, N. R. \& R. Cumaranatunga.1988. Egg production in the rainbow trout. Pp. 63-138. In: Muir, J. F. \& R. J. Roberts (Eds.). Recent advances in aquaculture. London, Croom Helm/ Timber Press.

Brown-Peterson, N., D. M. Wyanski, F. Saborido-Rey, B. J. Macewicz \& S. K. Lowerre-Barbieri. 2011. A standardized terminology for describing reproductive development in fishes. Marine and Coastal Fisheries, 3: 52-70.

Castranova, D. A., W. King \& L. C. Woods. 2005. The effects of stress on androgen production, spermiation response and sperm quality in high and low cortisol responsive domesticated male striped bass. Aquaculture, 246: 413-422.

Cleary, J. J., N. W. Pankhurst \& S. C. Battaglen. 2007. The effect of capture and handling stress on plasma steroid levels and gonadal condition in wild and farmed snapper Paragus auratus (Sparidae). Journal of the World Aquaculture Society, 31: 558-569.

Consten, D., J. Bogerd, J. Komen, J. G. Lambert \& H. J. Goos. 2001. Long-term cortisol treatment inhibits pubertal development in male common carp, (Cyprinus carpio L.) Biology of Reproduction, 64: 1063-1071.

Consten, D., J. G. Lambert, H. Komen \& H. J. Goos. 2002. Corticosteroids affect the testicular androgen production in male common carp (Cyprinus carpio L.). Biology of Reproduction, 66: 106-111.

Coward, K. \& N. Bromage. 1999. Spawning frequency, egg size and ovarian histology in groups of Tilapia zillii maintained upon two distinct food ration sizes from first-feeding to sexual maturity. Aquatic Living Resources, 12: 11-22.

Dias, R. M., D. Bailly, R. R. Antônio, H. I. Suzuki \& A. A. Agostinho. 2005. Colonization of the Corumbá Reservoir (Corumbá River, Paraná River Basin, Goiás State, Brazil) by the "lambari" Astyanax altiparanae (Tetragonopterinae; Characidae). Brazilian Archives of Biology and Technology, 48: 467-476.

Eigenmann, C. H. 1921. The American Characidae. Memoirs of the Museum of Comparative Zoölogy at Harvard College, 43: 227-310.

Garutti, V. 1989. Contribution to the knowledge of the reproduction of Astyanax bimaculatus (Ostariophysi, Characidae), in waters of the Paraná River basin. Revista Brasileira de Biologia,49: 489-495.

Garutti, V. \& H. A. Britski. 2000. Descrição de espécie nova de Astyanax (Teleostei: Characidae) da bacia do alto rio Paraná e considerações sobre as demais espécies do gênero na bacia. Comunicações do Museu de Ciências e Tecnologia da PUCRS, 13: $65-88$.

Godoy, M. P. 1975. Peixes do Brasil, subordem Characoidei, Bacia do rio Mogi Guaçu. Piracicaba, Editora Franciscana.

Goetz, F. W. \& G. Theofan.1979. In vitro stimulation of germinal vesicle breakdown and ovulation of yellow perch (Perca flavescens) oocytes. Effects of 17 $\alpha$-hydroxy20- dihydroprogesterone and prostaglandins. General and Comparative Endocrinology, 37: 273-285.

Haider, S. \& N. V. Rao. 1994. Induced spawning of maturing Indian catfish, Clarias batrachus (L.), using low doses of steroid hormones and salmon gonadotropin. Aquaculture Research, 25: 401-408. 
Lizama, M. A. P. \& A. M. Ambrosio. 2002. Condition factor in nine species of fish of the Characidae family in the Upper Paraná River floodplain, Brazil. Brazilian Journal of Biology, 62: 113-124.

Machado, C. E. M. 1975. Grandes Barragens e Meio Ambiente: dois aspectos importantes. São Paulo, CESP.

Marshall, C. T., N. Yaragina, Y. Lambert \& O. Kjesbu. 1999. Total lipid energy as a proxy for total egg production by fish stocks. Nature, 402: 288-290.

Milla, S., S. Wang, S. N. M. Mandiki \& P. Kestemont. 2009. Corticosteroids: friends or foes of teleost fish reproduction. Comparative Biochemistry and Physiology Part A, 153: 242251.

Milton, D. A., S. J. M. Blaber \& N. J. F. Rawlinson. 1994. Reproductive biology and egg production of three species of Clupeidae from Kiribati, tropical central Pacific. Fishery Bulletin, 92: 102-121.

Mosconi, G., G. Cardinaletti, M. Carotti, F. Palermo, L. Soverchia \& A. M. Polzonetti-Magni. 2006. Neuroendocrine mechanisms regulating stress response in cultured teleost species. Pp. v.2, 693-720. In: Reinecke, M., G. Zaccone \& B. G. Kapoor (Eds.). Fish Endocrinology. New Hampshire Enfield, Science Publishers.

Mylonas, C. C. \& Y. Zohar. 2007. Promoting oocyte maturation, ovulation and spawning in farmed fish. Pp. 437-474. In: Babin, P. J., J. Cerdà \& E. Lubzens (Eds.). The Fish Oocyte: from basic studies to biotechnological applications. Dordrecht, Netherlands, Springer.

Nomura, H. 1975. Fecundidade, maturação sexual e índice gônadosomático de lambari do gênero Astyanax Baird \& Girard, 1854 (Osteichthyes, Characidae), relacionados com fatores ambientais. Revista Brasileira de Biologia, 35: 775-798.

Ozaki, Y., M. Higuchi, C. Miura, S. Yamaguchi, Y. Tozawa \& T. Miura. 2006. Roles of 11ßhydroxysteroid dehydrogenase in fish spermatogenesis. Endocrinology, 147: 5139-5146.

Pankhurst, N. W. \& G. Van Der Kraak. 2000. Evidence that acute stress inhibits ovarian steroidogenesis in rainbow trout in vivo, through the action of cortisol. General and Comparative Endocrinology, 117: 225-237.

Pereira-Filho, H. P., D. R. Andrade, W. C. T. Tonini \& M. V. VidalJunior. 2011. Biologia reprodutiva de fêmeas de lambari-prata, Astyanax scabripinnis, 1842 (Characidae; Tetragonopterinae, Teleostei) em condições de cativeiro. Ciência Animal Brasileira, Goiânia, 12: 626-634.

Peres, M. D., M. S. Vasconcelos \& E. Renesto. 2005. Genetic variability in Astyanax altiparanae Garutti \& Britski, 2000 (Teleostei, Characidae) from the Upper Paraná River basin, Brazil. Genetics and Molecular Biology, 28: 717-724.

Porto-Foresti, F., C. Oliveira, F. Foresti \& R. B. Castilho-Almeida. 2001. Cultivo do Lambari: Uma espécie de pequeno porte e grandes possibilidades. Panorama da Aquicultura, 11: 15-19.

Quagio-Grassiotto, I., H. Grier, T. S. Mazzoni, R. H. Nóbrega \& J. P. A. Amorim. 2011. Activity of the ovarian germinal epithelium in the freshwater catfish, Pimelodus maculatus (Teleostei: Ostariophysi: Siluriformes): germline cysts, follicle formation and oocyte development. Journal of Morphology, 272: 1290-1306.

Rocha, M. J. \& E. Rocha. 2006. Morphofunctional aspects of reproduction from synchronous to asynchronous fishes- An overview. Pp. 572-624. In: Reinecke, M., G. Zaccone \& B. G. Kapoor (Eds.).Fish Endocrinology. New Hampshire, Science Publishers, Enfield.
Rodrigues, A. M., E. C. Campos, R. A. Santos, J. MandelliJunior \& J. J. C. Camara. 1992. Tipo de desova e fecundidade do tambiú Astyanax bimaculatus Linnaeus, 1758 (Pisces, Characiformes, Characidae), na represa de Ibitinga, Estado de São Paulo, Brasil. Brazilian Journal of Veterinarian Research and Animal Science, 20: 309-315.

Schreck, C. B. 2010. Stress and fish reproduction: The roles of allostasis and hormesis. General and Comparative Endocrinology, 165: 549-556.

Schreck, C. B., W. Contreras-Sanchez \& M. S. Fitzpatrick. 2001. Effects of stress in fish reproduction, gamete quality and progeny. Aquaculture, 197: 3-24.

Schulz, R. W., L. R. França, J. J. Lareyre, F. Legac, H. ChiariniGarcia, R. H. Nóbrega \& T. Miura. 2010. Spermatogenesis in fish. General and Comparative Endocrinology, 165: 390-3

Small, B. C. 2004. Effect of dietary cortisol administration on growth and reproductive success of channel catfish. Journal of Fish Biology, 64: 589-596.

Somarakis, S., E. K. Ganias, E. G. Tserpes \& C. Koutsikopoulos. 2004. Ovarian allometry and the use of the gonosomatic index: a case study in the Mediterranean sardine, Sardina pilchardus. Marine Biology, 146: 181-189.

Sundararaj, B. I., V. Lamba \& S. V. Goswami. 1980. Seasonal reproduction in fish. Steroids profiles in annually breeding fish. Pp. 267-272. In: Cumming, I. A., J. W. Funder \& F.A.O. Mendelsohn (Eds.).Endocrinology. Canberra, Australian Academy of Sciences.

Sundararaj, B. I. \& S.Vasal.1976. Photoperiod and temperature control in the regulation of reproduction in the female catfish, Heteropneus tesfossilis. Journal of the Fisheries Research Board of Canada, 33: 959-973.

Suzuki, H. I., A. E. A. M. Vazzoler, E. E. Marques, M. A. Perez-Lizama \& P. Inada. 2004. Reproductive ecology of the fish assemblages. Pp. 271-292. In: Thomaz, S. M., A. A. Agostinho, N. S. Hahn (Eds.).The Upper Paraná River and its Floodplain: physical aspects, ecology and conservation. Leiden, Netherlands, Backhuys Publishers.

Suzuki, H. I., C. K. Bulla, A. A. Agostinho \& L. C. Gomes. 2005. Estratégias reprodutivas de assembleias de peixes em reservatórios. Pp. 223-236. In: Rodrigues, L., S. M. Thomaz, A. A. Agostinho \& L. C. Gomes (Orgs.). Biocenoses em Reservatórios: padrões espaciais e temporais. São Carlos, RiMa Editora.

Vazzoler, A. E. A. M. 1996. Biologia da Reprodução de Peixes Teleósteos: teoria e prática. Maringá, Eduem; São Paulo, SBI.

Westring, C. G., H. Ando, T. Kitahashi, R. K. Bhandari, H. Ueda, A. Urano, R. M. Dores, A. A. Sher \& P. B. Danielson. 2008. Seasonal changes in CRF-I and urotensin I transcript levels in Masu salmon: Correlation with cortisol secretion during spawning. General and Comparative Endocrinology, 155: 126-140.

Zohar, Y., A. Goren, M. Tosky, G. Pagelson, D. Leibovitz \& Y. Koch. 1989. The bioactivity of gonadotropin-releasinghormones and its regulation in the gilthead seabream, Sparus aurata: in vivo and in vitro studies. Fish Physiology and Biochemistry, 7: 59-67.

Submitted February 17, 2014 Accepted October 6, 2014 by Clarice Fialho Published March 31, 2015 
